\title{
Local Perception of Tourism Development: A Conceptual Framework for the Sustainable Cultural Tourism
}

\author{
Sharareh AbbasiDorcheh ${ }^{1} \&$ Badaruddin Mohamed $^{1}$ \\ ${ }^{1}$ School of Housing, Building and Planning, Universiti Sains Malaysia, Penang, Malaysia \\ Correspondence: Sharareh AbbasiDorcheh, School of Housing, Building and Planning, Universiti Sains Malaysia, \\ Penang, Malaysia. E-mail: shararehabbasi@gmail.com
}

Received: October 10, 2012 Accepted: November 19, 2012 Online Published: February 26, 2013

doi:10.5539/jms.v3n2p31 URL: http://dx.doi.org/10.5539/jms.v3n2p31

\begin{abstract}
Tourism scholars believe that local perception has been an important subject of research involving tourism industry, despite the fact that there is a great deal of articles and studies on local perception of tourism development. The question is how we can balance preserving the tradition and making the necessary adjustment to provide the needs of the place as a tourist destination without exploiting (use unfairly) the local community and distracting their life. This paper aims to review existing literature on local perception of tourism development and its process. It also discusses influential theories and explains the social exchange theory as an effective framework for the sustainable cultural tourism.
\end{abstract}

Keywords: local perception, tourism development, sustainable tourism, cultural tourism, social exchange

\section{Introduction}

Researchers have identified tourism as one of the biggest and fastest growing industry around the world. In addition, there are great deals of discourse on cultural tourism which is extremely an important component of the industry. Moreover, all experts and researchers agree that for better understanding of cultural tourism, we must know how the world heritage sites are used in fulfilling their vital needs. Currently, most experts in the field of tourism are concerned with the impact of the excessive development of tourism. This, accordingly, has provoked a lot of discussions about sustainable tourism.

The concept of sustainable tourism was adapted from the idea of sustainable development which is development that takes care of the needs of the present generations without challenging the ability of future generations to meet their own needs. Theories of sustainability (Butler, 1999; Hardy et al., 2002) encouraged by the debate Rio Earth Summit's 21 key principles for sustainable development and its Agenda of 21 goals. World tourism organization defined sustainable tourism as: "Tourism that takes full account of its current and future economic, social and environmental impacts, addressing the needs of visitors, the industry, and the environment and host communities" (World Tourism Organization, 1993, p. 7).

World tourism organization (WTO) emphasizes that Sustainable tourism development guidelines and management practices are appropriate to all forms of tourism in all types of destinations, including mass tourism and the various type of tourism. Accordingly, the environmental, economic, and socio-cultural aspects of tourism development are the most important dimension of sustainable development. Moreover, an acceptable balance between these three conditions is essential to guarantee long-term sustainability. It seems impossible to say whether a specific tourism destination or activity is sustainable, nonetheless, to pay attention to some indicators of sustainable tourism is necessary.

For instance:

1) Making optimal use of the environmental and natural resources with consideration of present and future requirements.

2) Showing respect and admiration to the socio-cultural reality and truth of local communities, by protecting their building and world heritage sites.

3) Defending local community's rights and providing socio-economic benefits to all stakeholders (Eber, 1992; Nordic World Heritage Office, 1999; Payne, 1993). 
Based on previous discussion, the United Nations Educational, Scientific and Cultural Organization (UNESCO) made an effort to encourage the identification, protection and preservation of cultural and natural heritage around the world considered to be of outstanding value to humanity. UNESCO described Cultural heritage as "monuments, groups of buildings and sites with historical, aesthetic, archaeological, scientific, ethnological or anthropological value" (UNESCO, 2008).

\section{Definition of Cultural Tourism}

There is a universal agreement in the tourism industry that cultural tourism is an incredibly difficult thing to define and there seems to be little agreement on what actually constitutes "cultural tourism". Additionally, it can be difficult to separate "culture" and "heritage" in the mind of the consumer as they are inherently linked.

The UNESCO World Commission on Culture and Development report Our Creative Diversity looks at culture as ways of living together. The World Bank defines culture "As the whole complex of distinctive spiritual, material, intellectual and emotional features that characterize a society or social group. It includes not only arts and letters, but also modes of life, the fundamental rights of the human being, value systems, traditions, and beliefs". (Nordic World Heritage Office, 1999) This definition refers to both tangible and intangible factors. These factors are commonly cited by researchers.World Tourism Organization (2005, p. 3) noted an operational definition of cultural tourism: "All movements of persons to specific cultural attractions, such as heritage sites, artistic and cultural manifestations, arts and drama to cities outside their normal country of residence".

Culture and cultural heritage affects people's identity, self-respect, and dignity. Besides, today we can observe increasing demand for cultural heritage sites. Festivals and events are important for cultural tourism throughout the world. Furthermore, they help to maintain, keep and store cultural traditions and values of societies. Remarkably, they are the cause of benefit and making better situation for local communities in all cultural areas (Nordic World Heritage Office, 1999).

According to The European Association of Historic Towns and Regions (EAHTR, 2006) the principles of sustainable cultural tourism are:

1) Attention to climate changes as a critical and uncomplimentary global issue i.e. trying to reduce carbon emissions.

2) Attention to intrinsic value to the cultural heritage of historic towns and cities.

3) Showing respect and admiration to reality and truth, exceptional qualities, rights and beliefs of local cultures and support approaches to cultural tourism.

4) Cultural tourism as an economically important activity should contribute to an overall schedules and agendas of sustainable development.

5) Preserving and conserving cultural heritage assets and contribute to achieving this.

6) Pay attention to the needs of local communities and host community should be getting involved in development and planning.

7) Justice and fairness are crucial to long term sustainability and cultural tourism should provide benefits equitably to the local communities.

8) Efficient and effective management requires well organized action and all local stakeholders including local government and politics, local groups of people and businesses, must be involved in the development of cultural tourism.

9) Cultural tourism must react and respond to the lacking things of visitor and help to achieving a high quality visitor experience.

10) The impact of tourism should be assessed according to the value of consumers and producers.

11) The management and development of cultural tourism should be responsive to change.

Based on the above definition of sustainable and cultural tourism, and according to the principles of sustainable cultural tourism, we can observe the growing importance of stakeholders and local communities in heritage management and planning. In addition, involvement of all stakeholders in planning and decision making is fundamental to preserving and conservation of cultural resources.

The balance between conservation and the use of heritage sites is essential for many heritage sites, because tourism is one of the core income-generating activities. Therefore, increasing tourism activities may result in vital issues for heritage conservation. How do we balance between preserving the tradition and making necessary 
adjustment to provide the needs of the place as a tourist destination without exploiting (use unfairly) the local communities and distracting their life? Do local people enjoy the advantages of their culture? Do they understand the importance of their culture? Do they know about tourism?

Responding to these challenges, the roles of new actors from private sectors and developers are crucial and participation of local population (stakeholder involvement and local community) is needed.

This paper aims to review existing literature on residents' perception of tourism development and its process. This paper discusses theories and explains the social exchange and stakeholder theory as an effective framework for achieving the sustainable cultural tourism.

\section{Review of Literature}

There are two major groups inside of sustainable cultural tourism literature. First, studies which emphasis on the importance of exact definitions and determining definite conception of the sustainable cultural tourism (Butler, 1999; Clarke, 1997; Hunter, 1997) second groups emphasis on the importance of indicators and the abilities of application of the sustainable cultural tourism in all tourism destinations (Bramwell \& Lane, 2011; Choi \& Sirakaya, 2006; Du Cros, 2001; Garrod \& Fyall, 1998; Lozano-Oyola et al., 2012; Ngamsomsuke et al., 2011).

Journal of Cultural Heritage Management and Sustainable Development in recent volume (Roders \& van Oers, 2011a, 2011b, 2012) provide some evidence about guidance and significant relationship between cultural heritage and sustainable tourism. This journal also assigned another volume (Van Oers \& Roders, 2012) to discuss about the principles of sustainable urban heritage management and its essential role for historic cities. In this regard, some studies explored the issue of sustainable urban development in the cultural context (Al-hagla, 2010; Choi \& Ahn, 2012).

In the case of cultural development model, Abankina (2012) described three development model related to cultural heritage resources. He compared three regional development models including: evolution development model (Great Britain), deindustrialization model (Germany), and enclave model (Russia). Finding illustrated differences among potential of cultural resources in these three areas. In the field of regional development related to sustainable cultural tourism, Vargas-Hernández (2012) used normative model for recognized strength and weakness of Southern Jalisco (Mexico) as a cultural destination. The result of this study provided some suggestion for better implications of the principles of sustainable cultural tourism in that area.

Studies on resident attitudes toward tourism development date back to the 1970s. Researchers note that understanding and assessing tourism development in level of local communities is essential for achieving continued sustainable tourism (Burns \& Sancho, 2003; Diedrich \& García-Buades, 2009; Johnson et al., 1994; Liu \& Var, 1986; Ryan \& Montgomery, 1994; Tosun, 2001; Upchurch \& Teivane, 2000; Weaver \& Lawton, 2001; Williams \& Lawson, 2001). A decrease in tourism market could be deteriorating when an economy becomes wildly dependent on tourism industry. Scholars suggest using a theoretical relationship as a point of convergence of opinion for achieving sustainability and combined principles can be helpful for reducing disconnection in the tourism literature while becoming and making strong predictive capabilities.

In the great deal of studies, to explore the interrelationship between local perception of tourism development experts use numbers of theoretical models including Butler's tourism area life cycle (1980), social exchange theory (Ap, 1992), Doxey's Irridex model (Doxey, 1976), stakeholder theory (Freeman, 1984), Reasoned action (Ajzen \& Fishbein, 1980).

In a tourism context, vast majority of studies categorize resident attitudes toward tourism development under the economic, social and environmental dimensions (Andereck et al., 2005; Dyer et al., 2007; Ghaderi \& Henderson, 2012; Jimura, 2011; Kuvan \& Akan, 2005; Lawson et al., 1998; Lee, 2012; Liu \& Var, 1986; Mason \& Cheyne, 2000; Nicholas et al., 2009).

The results of some surveys indicate that residents have favorable attitudes toward tourism development but also they are concerned about negative effects of tourism (Andereck et al., 2005; Dyer et al., 2007; Ghaderi \& Henderson, 2012; Haralambopoulos \& Pizam, 1996; Jimura, 2011; Korça, 1998; Kuvan \& Akan, 2005; Lee, 2012; Lepp, 2007; Nicholas et al., 2009; Pizam, 1978; Thomason et al., 1979; Yoon et al., 1999; Zamani-Farahani \& Musa, 2008).

Community participation is one of new notions of post-industrial era and it is from political area. Tourism community involvement is considered as a fundamental subject of sustainable tourism development. Authors noted various factors that affect resident attitudes including residents' level of involvement in tourism, type of tourism development, socio-demographic characteristics, distance residents live from tourism areas and contact 
with tourists (Andereck et al., 2005; King et al., 1993; Kuvan \& Akan, 2005; Lepp, 2007; Nicholas et al., 2009; Teye et al., 2002).

Tosun (2000) widely explains the community participation in the context of the tourism development process in developing countries. He also describes and analyses three strong limitations such as operational, structural and cultural limitations (Tosun, 2006). The author noted that community involvement in tourism context can be considered from at least two viewpoints: in the decision-making process and in the benefits of tourism development.

In this regard Nyaupane et al. (2006) examine the role of community involvement and number of visitors on tourism impacts.

In some studies, special emphasis is placed on the effect of community identities on heritage tourism. In this respect, Ruiz Ballesteros and Hernández Ramírez (2007) demonstrate a relationship between identities and community; they identified the role of the symbolic community in development of heritage tourism. In addition, they accepted the influence of tourism on identities. This approach is used to highlight the role of local societies in the development and sustainability of mining heritage tourism in southern Spain.

In one of its many interpretations Simpson (2008) asked about community benefit tourism initiatives (CBTIs) as a conceptual oxymoron. He conceded that community involvement would be fortunate at all stages in the initiative for both developed and developing countries. He also examined and introduced this concept and identified some features that are crucial on shaping community development based on the principles of sustainable tourism.

Recently, Frauman and Banks (2011) examined resident perceptions of community and tourism development in a gateway area. The authors looked at the relationship between the importance of various attributes and features in the county and perception of the current conditions of the attributes and features across four types of residents via the incorporation of a modified importance performance analysis.

Pursuant to this, heritages are regarded as one of the most significant and fastest growing components of tourism. Along with this, researchers investigated the link between heritage and tourism. In addition, some studies predicted and illustrated certain possible tourism impacts. These impacts could be traced in changes in use and look of buildings, overcrowding of site, commercialization of local culture, the issue of management and conservation (Jimura, 2011; Nicholas et al., 2009).

Most studies have recognized stakeholders groups having fundamental role in the story of tourism development(Byrd, 2007; Byrd et al., 2009; Hunter, 1997; Nicholas et al., 2009; Richards \& Hall, 2000). Therefore, stakeholder support for achieving sustainable tourism development is vital. The important point is that a clear understanding of attitudes and interests of stakeholders helps reaching comprehensive planning and management which leads to sustainable tourism development.

Byrd et al. (2009) categorize majority of studies about stakeholders and they emphasize that there are a great deal of studies which consider the role of stakeholders and their attitudes. Conversely, there are a few research which comparing multiple stakeholder groups in a society. Interestingly, comparisons of multiple stakeholder groups have shown differences in the attitudes and perception of tourism between four major groups: 1-residents 2- entrepreneurs 3- tourists 4- local governmental officials.

In the discussion of local perception, Lepp (2007) has shown a connection between resident' attitudes and their behavioral intention. He used the theory of reasoned action (Ajzen \& Fishbein, 1980) for identifying residents' attitudes toward tourism in Bigodi which is a village of approximately 385 adults has been involved with tourism since 1991. The results indicate that residents have positive attitudes towards tourism. Accordingly, they believe that tourism brought for them lots of job opportunities and higher standard of life in compare of past. It means that one of the main causes of creating pro-tourism behavior is positive perspective toward tourism. Researchers note that some variables which are useful for measuring this relationships, are: "enjoyment of benefits, involvement with decision making, stage of destination life cycle, tourist type, economic dependence on tourism, degree of cultural difference between residents and tourist" (Andereck et al., 2005; Kuvan \& Akan, 2005; Lepp, 2007; Teye et al., 2002).

In line with this, an International conference on cultural tourism and local community was held in Yogyakarta, Indonesia, on February 2006. Tourism scholars and researchers presented several studies and speeches related to community participation, the role of cultural tourism, sustainable tourism plans, conservation of heritage resources, government and policy making. The point is that most of these studies were done in Asian countries (World Tourism Organization, 2006). 
In the discussion of social exchange theory, there are two distinct traditions, the "collectivistic" one by Levi-Strauss, and the "individualistic" one by Homans. The French collectivistic tradition in sociology has made a major impact in the area of sociological theory called social exchange. Homans' exchange theory was a reaction to an older theory of social exchange in a different tradition of thought (Ekeh, 1974; Heath, 1976).

\section{Social Exchange Theory}

Ap (1992) explains social exchange theory as "a general sociological theory concerned with understanding the exchange of resources between individuals and groups in an interaction situation". According to this paradigm in a society people always seek and follow something valuable. It means that the perceived value of the outcome is one of the main dimensions for determining the residents' perception toward tourism.

It appears that there is a tendency for using social exchange theory as a basic theoretical framework for many studies (Andereck et al., 2005; Byrd et al., 2009; Gursoy et al., 2002; Jurowski et al., 1997; Kuvan \& Akan, 2005; Lindberg \& Johnson, 1997; McGehee \& Andereck, 2004; Perdue et al., 1990; Teye et al., 2002).

Andereck et al. (2005) explains that "stakeholders' attitudes toward and support for tourism in their community will be influenced by their evaluations of the actual and perceived outcomes tourism has in their community". In other words, cost and benefits determined qualities of an action in a social interaction, because people evaluate a specific situation and after that decided based on their perceived.

Previous studies almost emphasis on significant of process of exchange in a society and their effect on local perceptions of tourism development or tourism impact but Moyle et al. (2010) examined the cultural interaction between local communities and visitor in Bruny Island and Magnetic Island where located in Tasmania and Queensland, Australia. The result of this comparative study illustrated a range of economical motivation between them.

In sum, from a tourism standpoint social exchange means that if perception of local community is base on benefit from an exchange they evaluate it positively and therefore they help to promote and develop tourism; conversely if their perception is based on costs, their evaluation is negative. Accordingly, residents who have personal benefit or dependency on the industry tend to have more positive perception of impacts.

\section{Conclusion}

This paper tries to discuss the importance of local perception of tourism development for achieving sustainable cultural tourism. First, it defines sustainable and cultural tourism and explains the principles of sustainable cultural tourism. Then, we formulated most important research and studies about local perception. A review on related literature on local perception toward tourism development indicate that understanding and assessing tourism development in communities is essential in order to maintain sustainability and long-term success of the tourism industry.

In this regard, vast majority of studies categorize resident attitudes toward tourism development under the economic, social and environmental dimensions. Moreover, community involvement is considered as a fundamental subject of sustainable tourism development. Furthermore, most studies have recognized stakeholders groups having fundamental role in the scenario of tourism development. Hence, this paper by reviewing literature on the local perception and their attributes is proposing social exchange theory as a prevalent theory. The proposed theories that have been drawn from tourism literature need empirical examination to confirm. Further study is suggested to investigate the application of these theories for achieving the sustainable cultural tourism.

\section{Acknowledgements}

The authors would like to extent their appreciation to the Ministry of Higher Education's LRGS grant entitled conceptualizing a national multi-dimensional Responsible Rural Tourism Capacity (RRTC) framework and to the Universiti Sains Malaysia for the Sustainable Tourism Research Cluster Grant which made this paper possible.

\section{References}

Abankina, T. (2012). Regional development models using cultural heritage resources. International Journal of Culture, Tourism and Hospitality Research, 7(1), 1-1.

Ajzen, I., \& Fishbein, M. (1980). Understanding attitudes and predicting social behavior (vol. 278). Prentice-Hall. 
Al-hagla, K. S. (2010). Sustainable urban development in historical areas using the tourist trail approach: A case study of the Cultural Heritage and Urban Development (CHUD) project in Saida, Lebanon. Cities, 27(4), 234-248. http://dx.doi.org/10.1016/j.cities.2010.02.001

Andereck, K. L., Valentine, K. M., Knopf, R. C., \& Vogt, C. A. (2005). Residents' perceptions of community tourism impacts. Annals of Tourism Research, 32(4), 1056-1076. http:dx.doi.org/10.1016/j.annals.2005.03.001

Ap, J. (1992). Residents' perceptions on tourism impacts. Annals of Tourism Research, 19(4), 665-690. http://dx.doi.org/10.1016/0160-7383(92)90060-3

Bramwell, B., \& Lane, B. (2011). Critical research on the governance of tourism and sustainability. Journal of Sustainable Tourism, 19(4-5), 411-421. http://dx.doi.org/10.1080/09669582.2011.580586

Burns, P. M., \& Sancho, M. M. (2003). Local perceptions of tourism planning: the case of Cuellar, Spain. Tourism Management, 24, 331-339. http://dx.doi.org/10.1016/S0261-5177(02)00069-9

Butler, R. W. (1980). The concept of a tourist area cycle of evolution: implications for management of resources. Canadian Geographer/Le Géographe canadien, $24(1), \quad 5-12$. http://dx.doi.org/10.1111/j.1541-0064.1980.tb00970.x

Butler, R. W. (1999). Sustainable tourism: A state-of-the-art review. Tourism Geographies, 1(1), 7-25. http://dx.doi.org/10.1080/14616689908721291

Byrd, E. T. (2007). Stakeholders in sustainable tourism development and their roles: applying stakeholder theory to sustainable tourism development. Tourism Review, 62(2), 6-13. http://dx.doi.org/10.1108/16605370780000309

Byrd, E. T., Bosley, H. E., \& Dronberger, M. G. (2009). Comparisons of stakeholder perceptions of tourism impacts in rural eastern North Carolina. Tourism Management, 30(5), 693-703. http://dx.doi.org/10.1016/j.tourman.2008.10.021

Choi, H., \& Ahn, K. H. (2012). Assessing the sustenance and evolution of social and cultural contexts within sustainable urban development, using as a case the MAC in South Korea. Sustainable Cities and Society. http://dx.doi.org/10.1016/j.scs.2012.08.003

Choi, H., \& Sirakaya, E. (2006). Sustainability indicators for managing community tourism. Tourism Management, 27(6), 1274-1289. http://dx.doi.org/10.1016/j.tourman.2005.05.018

Clarke, J. (1997). A framework of approaches to sustainable tourism. Journal of Sustainable Tourism, 5(3), 224-233. http://dx.doi.org/10.1080/09669589708667287

Diedrich, A., \& García-Buades, E. (2009). Local perceptions of tourism as indicators of destination decline. Tourism Management, 30(4), 512-521. http://dx.doi.org/10.1016/j.tourman.2008.10.009

Doxey, G. (1976). When enough's enough: The natives are restless in Old Niagara. Heritage Canada, 2(2), 26-27.

Du Cros, H. (2001). A new model to assist in planning for sustainable cultural heritage tourism. International Journal of Tourism Research, 3(2), 165-170. http://dx.doi.org/10.1002/jtr.297

Dyer, P., Gursoy, D., Sharma, B., \& Carter, J. (2007). Structural modeling of resident perceptions of tourism and associated development on the Sunshine Coast, Australia. Tourism Management, 28(2), 409-422. http://dx.doi.org/10.1016/j.tourman.2006.04.002

EAHTR. (2006). Sustainable cultural tourism in historic towns and cities. United Kingdom.

Eber, S. (1992). Beyond the green horizon: principles for sustainable tourism. World Wide Fund for Nature (WWF).

Ekeh, P. P. (1974). Social exchange theoty the two traditions. London: Heinemann.

Frauman, E., \& Banks, S. (2011). Gateway community resident perceptions of tourism development: Incorporating Importance-Performance Analysis into a Limits of Acceptable Change framework. Tourism Management, 32(1), 128-140. http://dx.doi.org/10.1016/j.tourman.2010.01.013

Freeman, R. (1984). Strategic Management: a stakeholder approach. New York: Cambridge University.

Garrod, B., \& Fyall, A. (1998). Beyond the rhetoric of sustainable tourism? Tourism Management, 19(3), 199-212. http://dx.doi.org/10.1016/S0261-5177(98)00013-2 
Ghaderi, Z., \& Henderson, J. C. (2012). Sustainable rural tourism in Iran: A perspective from Hawraman Village. Tourism Management Perspectives, 2, 47-54. http://dx.doi.org/10.1016/j.tmp.2012.03.001

Gursoy, D., Jurowski, C., \& Uysal, M. (2002). Resident attitudes:: A Structural Modeling Approach. Annals of Tourism Research, 29(1), 79-105. http://dx.doi.org/10.1016/S0160-7383(01)00028-7

Haralambopoulos, N., \& Pizam, A. (1996). Perceived impacts of tourism: The case of Samos. Annals of Tourism Research, 23(3), 503-526. http://dx.doi.org/10.1016/0160-7383(95)00075-5

Hardy, A., Beeton, R. J. S., \& Pearson, L. (2002). Sustainable tourism: An overview of the concept and its position in relation to conceptualisations of tourism. Journal of Sustainable Tourism, 10(6), 475-496. http://dx.doi.org/10.1080/09669580208667183

Heath, A. (1976). Rational choice and social exchange: A critique of exchange theory. Cambridge University Press.

Hunter, C. (1997). Sustainable tourism as an adaptive paradigm. Annals of Tourism Research, 24(4), 850-867. http://dx.doi.org/10.1016/S0160-7383(97)00036-4

Jimura, T. (2011). The impact of world heritage site designation on local communities-A case study of Ogimachi, Shirakawa-mura, Japan. Tourism Management, 32(2), 288-296. http://dx.doi.org/10.1016/j.tourman.2010.02.005

Johnson, J. D., Snepenger, D. J., \& Akis, S. (1994). Residents' perceptions of tourism development. Annals of Tourism Research, 21(3), 629-642. http://dx.doi.org/10.1016/0160-7383(94)90124-4

Jurowski, C., Uysal, M., \& Williams, D. R. (1997). A theoretical analysis of host community resident reactions to tourism. Journal of travel research, 36(2), 3-11. http://dx.doi.org/10.1177/004728759703600202

King, B., Pizam, A., \& Milman, A. (1993). Social impacts of tourism:: Host perceptions. Annals of Tourism Research, 20(4), 650-665. http://dx.doi.org/10.1016/0160-7383(93)90089-L

Korça, P. (1998). Resident perceptions of tourism in a resort town. Leisure Sciences, 20(3), 193-212. http://dx.doi.org/10.1080/01490409809512280

Kuvan, Y. Á. I., \& Akan, P. (2005). Residents' attitudes toward general and forest-related impacts of tourism: the case of Belek, Antalya. Tourism Management, 26(5), 691-706. http://dx.doi.org/10.1016/j.tourman.2004.02.019

Lawson, R., Williams, J., Young, T., \& Cossens, J. (1998). A comparison of residents' attitudes towards tourism in 10 New Zealand destinations. Tourism Management, 19(3), 247-256. http://dx.doi.org/10.1016/S0261-5177(98)00018-1

Lee, T. H. (2012). Influence analysis of community resident support for sustainable tourism development. Tourism Management. http://dx.doi.org/10.1016/j.tourman.2012.03.007

Lepp, A. (2007). Residents' attitudes towards tourism in Bigodi village, Uganda. Tourism Management, 28(3), 876-885. http://dx.doi.org/10.1016/j.tourman.2006.03.004

Lindberg, K., \& Johnson, R. L. (1997). Modeling resident attitudes toward tourism. Annals of Tourism Research, 24(2), 402-424. http://dx.doi.org/10.1016/S0160-7383(97)80009-6

Liu, J. C., \& Var, T. (1986). Resident attitudes toward tourism impacts in Hawaii. Annals of Tourism Research, 13(2), 193-214. http://dx.doi.org/10.1016/0160-7383(86)90037-X

Lozano-Oyola, M., Blancas, F. J., González, M., \& Caballero, R. (2012). Sustainable tourism indicators as planning tools in cultural destinations. Ecological Indicators. http://dx.doi.org/10.1016/j.ecolind.2012.01.014

Mason, P., \& Cheyne, J. (2000). Residents' attitudes to proposed tourism development. Annals of Tourism Research, 27(2), 391-411. http://dx.doi.org/10.1016/S0160-7383(99)00084-5

McGehee, N. G., \& Andereck, K. L. (2004). Factors predicting rural residents' support of tourism. Journal of travel research, 43(2), 131-140. http://dx.doi.org/10.1177/0047287504268234

Moyle, B., Croy, G., \& Weiler, B. (2010). Tourism interaction on islands: the community and visitor social exchange. International Journal of Culture, Tourism and Hospitality Research, 4(2), 96-107. http://dx.doi.org/10.1108/17506181011045172 
Ngamsomsuke, W., Hwang, T. C., \& Huang, C. J. (2011). Sustainable Cultural Heritage Tourism Indicators. Paper presented at the International Conference on Social Science and Humanity, Singapore.

Nicholas, L. N., Thapa, B., \& Ko, Y. J. (2009). Residents' perspectives of a world heritage site: The Pitons Management Area, St. Lucia. Annals of Tourism Research, 36(3), 390-412. http://dx.doi.org/10.1016/j.annals.2009.03.005

Nordic World Heritage Office. (1999). Sustainable Tourism and Cultural Heritage. A Review of Development Assistance and its Potential to Promote Sustainability. Oslo: NWHO.

Nyaupane, G. P., Morais, D. B., \& Dowler, L. (2006). The role of community involvement and number/type of visitors on tourism impacts: A controlled comparison of Annapurna, Nepal and Northwest Yunnan, China. Tourism Management, 27(6), 1373-1385. http://dx.doi.org/10.1016/j.tourman.2005.12.013

Payne, R. (1993). Sustainable tourism: suggested indicators and monitoring techniques. Tourism and Sustainable Development: Monitoring, Planning, Managing. Department of Geography, University of Waterloo, Canada, 249-254.

Perdue, R. R., Long, P. T., \& Allen, L. (1990). Resident support for tourism development. Annals of Tourism Research, 17(4), 586-599. http://dx.doi.org/10.1016/0160-7383(90)90029-Q

Pizam, A. (1978). Tourism's impacts: The social costs to the destination community as perceived by its residents. Journal of travel research, 16(4), 8-12. http://dx.doi.org/10.1177/004728757801600402

Richards, G., \& Hall, D. (2000). The community: A sustainable concept in tourism development. Tourism and sustainable community development, 7, 1-13.

Roders, A. P., \& van Oers, R. (2011a). Editorial: bridging cultural heritage and sustainable development. Journal of Cultural Heritage Management and Sustainable Development, 1(1), 5-14. http://dx.doi.org/10.1108/20441261111129898

Roders, A. P., \& Van Oers, R. (2011b). Editorial: initiating cultural heritage research to increase Europe's competitiveness. Journal of Cultural Heritage Management and Sustainable Development, 1(2), 84-95. http://dx.doi.org/10.1108/20441261111171657

Roders, A. P., \& Van Oers, R. (2012). Guidance on Heritage Impact Assessments: learning from its application on World Heritage site management. Journal of Cultural Heritage Management and Sustainable Development, 2(2), 1-1. http://dx.doi.org/10.1108/20441261211273671

Ruiz Ballesteros, E., \& Hernández Ramírez, M. (2007). Identity and community-Reflections on the development of mining heritage tourism in Southern Spain. Tourism Management, 28(3), 677-687. http://dx.doi.org/10.1016/j.tourman.2006.03.001

Ryan, C., \& Montgomery, D. (1994). The attitudes of Bakewell residents to tourism and issues in community $\begin{array}{lllll}\text { responsive } & \text { tourism. } & \text { Tourism } & \text { Management, } & 15(5),\end{array}$ http://dx.doi.org/10.1016/0261-5177(94)90090-6

Simpson, M. C. (2008). Community benefit tourism initiatives--A conceptual oxymoron? Tourism Management, 29(1), 1-18. http://dx.doi.org/10.1016/j.tourman.2007.06.005

Teye, V., Sirakaya, E., \& Sönmez, S. (2002). Residents' attitudes toward tourism development. Annals of Tourism Research, 29(3), 668-688. http://dx.doi.org/10.1016/S0160-7383(01)00074-3

Thomason, P., Crompton, J. L., \& Kamp, B. D. (1979). A study of the attitudes of impacted groups within a host community toward prolonged stay tourist visitors. Journal of travel research, 17(3), 2-6. http://dx.doi.org/10.1177/004728757901700301

Tosun, C. (2000). Limits to community participation in the tourism development process in developing countries. Tourism Management, 21, 613-633. http://dx.doi.org/10.1016/S0261-5177(00)00009-1

Tosun, C. (2001). Challenges of sustainable tourism development in the developing world: the case of Turkey. Tourism Management, 22(3), 289-303. http://dx.doi.org/10.1016/S0261-5177(00)00060-1

Tosun, C. (2006). Expected nature of community participation in tourism development. Tourism Management, 27(3), 493-504. http://dx.doi.org/10.1016/j.tourman.2004.12.004

UNESCO. (2008). Operational Guidelines for the Implementation of the World Heritage Convention. Paris: UNESCO World Heritage Centre. 
Upchurch, R. S., \& Teivane, U. (2000). Resident perceptions of tourism development in Riga, Latvia. Tourism Management, 21(5), 499-507. http://dx.doi.org/10.1016/S0261-5177(99)00104-1

Van Oers, R., \& Roders, A. P. (2012). Historic cities as model of sustainability. Journal of Cultural Heritage Management and Sustainable Development, 2(1), 4-14. http://dx.doi.org/10.1108/20441261211223298

Vargas-Hernández, J. G. (2012). Sustainable cultural and heritage tourism in regional development of Southern Jalisco. World Journal of Entrepreneurship, Management and Sustainable Development, 8(2/3), 146-161. http://dx.doi.org/10.1108/20425961211247752

Weaver, D. B., \& Lawton, L. J. (2001). Resident perceptions in the urban-rural fringe. Annals of Tourism Research, 28(2), 439-458. http://dx.doi.org/10.1016/S0160-7383(00)00052-9

Williams, J., \& Lawson, R. (2001). Community issues and resident opinions of tourism. Annals of Tourism Research, 28(2), 269-290. http://dx.doi.org/10.1016/S0160-7383(00)00030-X

World Tourism Organization. (1993). Sustainable Tourism Development: Guide for Local Planners. Madrid: WTO.

World Tourism Organization. (2005). City Tourism \& Culture: The European Experience. Madrid, Spain: World Tourism Organization.

World Tourism Organization. (2006). A Report on the International Conference on Cultural Tourism and Local Community. Paper presented at the International Conference on Cultural Tourism and Local Community, Yogyakarta, Indonesia.

Yoon, Y., Gursoy, D., \& Joeph, S. (1999). An investigation of the relationship between tourism impacts and host communities' characteristics. Anatolia, 10(1), 29-44. http://dx.doi.org/10.1080/13032917.1999.9686970

Zamani-Farahani, H., \& Musa, G. (2008). Residents' attitudes and perception towards tourism development: A case study of Masooleh, Iran. Tourism Management, 29(6), 1233-1236. http://dx.doi.org/10.1016/j.tourman.2008.02.008 